\title{
ЭКОЛОГИЯ
}

UDK 574.2

doi: $10.17223 / 19988591 / 52 / 7$

\author{
Yulia A. Frank ${ }^{1,2}$, Egor D. Vorobiev ${ }^{1}$, Irina B. Babkina ${ }^{1}$, \\ Dmitry V. Antsiferov ${ }^{2}$, Danil S. Vorobiev ${ }^{1}$ \\ ${ }^{1}$ Tomsk State University, Tomsk, Russian Federation \\ ${ }^{2}$ Darwin LLC, Tomsk, Russian Federation
}

\section{Microplastics in fish gut, first records from the Tom River in West Siberia, Russia}

\author{
This study was supported by Tomsk State University under competitiveness \\ improvement program (Research Grant No 8.2.08.2020).
}

\begin{abstract}
This preliminary study investigated the abundance of microplastic particles in gastrointestinal tracts of the dace (Leuciscus leuciscus L.) from the Tom River, a large tributary of the Ob River in West Siberia. A total of 13 dace specimens of 2+ to 4+ years of age were studied. Microplastic particles extracted from fish guts were counted and classified by shapes and sizes. In average $204 \pm 28.7$ items of microplastics were detected for one dace specimen. Microplastic particles were categorized as fragments of irregular shape (70\%), spheres (16\%), films (7\%) and fibers (7\%), with size ranging from $<0.15$ to $2.00 \mathrm{~mm}$. The vast majority of detected microplastic particles (almost $80 \%)$ were less than $0.15 \mathrm{~mm}$ by their largest dimension. These data provide the first evidence of microplastics in fish from the Ob River system.
\end{abstract}

Key words: microplastics; aquatic pollution; rivers; hydrobionts; fish; food chains.

\section{Introduction}

In recent decades, plastic debris have been found in aquatic ecosystems around the world as a direct consequence of industrial, consumer waste and wastewater emissions [1]. Pollution of the marine environment with microplastics (particles $<5 \mathrm{~mm}$ ) is especially intensively studied. The number of studies analyzing the abundance of microplastics in the marine environment began to grow rapidly after 2004, when the seminal paper by Thompson et al. [2] had been published. Microplastics are currently defined as polymer particles smaller than $5 \mathrm{~mm}$ [3], or $1 \mathrm{~mm}$ [4] in the largest axis. Some authors also use the terms "large" and "small" for microplastics (2-5 $\mathrm{mm}$ and $0.5-2 \mathrm{~mm}$, respectively) [5].

The adverse effects of plastics when swallowed by hydrobionts, suffocating or entangling them, have been documented for a variety of marine species, so these 
materials were found hazardous to marine fauna [6]. Since plastic breaks down into smaller pieces in an aquatic environment to form microplastics, it is believed that it can enter food chains [6-7]. Both field and laboratory studies suggest that fish absorb micro-sized plastic particles, e.g. originating from synthetic clothing and cleaning products containing plastic granules [7-8]. Ingestion of microplastics by hydrobionts and their accumulation in food chains provides a potential pathway for the transfer of other pollutants and potentially toxic additives to living organisms up to humans with uncertain consequences for their health [9-12].

Most studies on microplastics abundance have focused on marine organisms. Microscopic plastic particles have been detected in marine benthic organisms, especially in bivalves [7, 13-15]. Several reports describe microplastics in the gut of marine fish. Microplastics were detected in semipelagic fish bogue (Boops boops L.) around the Balearic Islands [16]. Microplastic ingestion is documented in commercially relevant fish species from the Spanish Atlantic coast and Mediterranean Sea - Scyliorhinus canicula L., Merluccius merluccius L. and the Mullus barbatus L. [17-18]. Ingestion of anthropogenic microfibres and microfragments by the European anchovy (Engraulis encrasicolus L.) of the Mediterranean Sea has been recently studied [19].

Much less attention is paid to riverine fish. First evidence of microplastics ingestion by fish from the Amazon River was received not so long ago [20]. McNeish et al. [21] measured microplastic abundance in fish from three major tributaries of Lake Michigan, the Muskegon River, the Milwaukee River, and the St. Joseph River. The results obtained from these two and several other [22] studies suggested microplastic pollution is common in river food webs.

The aim of this research is to assess the ingestion of microplastics by fish from the Tom River, a large tributary of the Ob River in West Siberia. It should be noted that the abundance of microplastics in fish of the Ob River system has not been studied to date, as well as in fish in other rivers of Russia.

\section{Materials and Methods}

The object of the study was common dace, (Leuciscus leuciscus L.) from the Tom River in Western Siberia, Russia. L. leuciscus is a widespread freshwater fish of Cyprinidae family [23]. Thirteen specimens of common dace were caught using a fishing rod on the right bank of the Tom River within the city of Tomsk $\left(56^{\circ} 27^{\prime} 33^{\prime \prime} \mathrm{N}, 84^{\circ} 56^{\prime} 056^{\prime \prime E}\right)$ on April 01, 2020. Fish were frozen, transported to the laboratory and stored at $-20^{\circ} \mathrm{C}$ before the laboratory analysis. Subsequently, each fish was defrosted and examined.

The total length of the body (L) and the standard length (from the tip of the snout to the posterior end of the midlateral portion of the hypural plate, 1) were measured using a caliper to the nearest $1 \mathrm{~mm}$. Total weight $(\mathrm{Q})$ and body weight without viscera (q) (wet weight, $\pm 1 \mathrm{~g}$ ) were determined using an electronic balance. Scales were taken in the region of the dorsal fin (10-15 pcs. in each 
specimen). The fish age was determined by the number of annual rings on the fish scales using a dissecting microscope. The sex of the fish was determined visually by gonads as described by Pravdin [24].

The fish was dissected, the gastrointestinal tract (oesophagus, stomach, and intestine) was removed for further processing and stored at $-20{ }^{\circ} \mathrm{C}$ until analysis according to the method published by Bellas et al. [17]. To extract microplastics from the gut, we used modified protocol developed by Claessens et al. [25] based on acid digestion of the soft tissues. The digestion procedure consisted of $12 \mathrm{~h}$ destruction of the fish guts in $25 \mathrm{~mL}$ of $\mathrm{HNO}_{3}(22.5 \mathrm{M})$ at room temperature, followed by $2 \mathrm{~h}$ of boiling in a water bath. Then the mixture was diluted to $100 \mathrm{~mL}$ with $26 \% \mathrm{NaCl}$ solution for total salt concentration of $20 \%$ and left for additional $12 \mathrm{~h}$ for the density separation. After separation, the upper fraction was vacuum filtered using $0.45 \mu \mathrm{m}$ mixed cellulose ester membrane filter (MF-Millipore). Filters were rinsed with $2 \% \mathrm{KOH}$ solution for saponification of fats and inspected by light microscopy (stereomicroscope Micromed MC2) using digital camera and ToupView 3.7.6273 software.

The abundance of microplastics of different shape and sizes was evaluated as the number of particles per fish specimen. The microplastics particles extracted from fish guts were classified into four groups by their shape [26]: spheres, films, fibers/lines, and fragments of irregular shape (including foams). The particles of microplastics were also classified by their major dimension into seven groups: $<0.15 \mathrm{~mm}, 0.15-0.30 \mathrm{~mm}, 0.30-1.00 \mathrm{~mm}, 1.00-2.00 \mathrm{~mm}, 2.00-3.00 \mathrm{~mm}, 3.00-$ $4.00 \mathrm{~mm}$ and $4.00-5.00 \mathrm{~mm}$.

The Mann-Whitney U test [27] was used to compare differences in biological parameters and microplastics abundance. Statistically significant differences were considered at $p \leq 0.05$

\section{Results and Discussion}

This research analyzed the anthropogenic microparticles in the guts of the dace (Leuciscus leuciscus L.) from the Tom River, the right tributary of the $\mathrm{Ob}$ River. The daces caught in the Tom River on April 01, 2020 were represented by three age groups: $2+$ years (4 specimens), $3+$ years ( 7 specimens), and $4+$ years ( 2 specimens). The sex ratio in the group was: females -3 specimens $(23 \%)$, males - 10 specimens (77\%). The dimensional features of the fish specimens are presented in Table 1. Statistical comparison of microplastics abundance in the gastrointestinal tract of fish using the nonparametric Mann-Whitney test did not reveal significant differences between groups of males and females, as well as between groups of different ages $(2+$ and $3+)$.

According to the analysis results, $204 \pm 28.7$ items of microplastics were detected in each dace specimen (Table 2). The found value for total microplastic particles per fish (items fish ${ }^{-1}$ ) is quite high. The average of microparticle content in the gut of the Mediterranean Sea fish were $<1.00$ items per fish for anchovies [19] 
and $1.56 \pm 0.50$ items per fish for the red mullet [17]. The number of microplastics found in the gastrointestinal tract of Dicentrarchus labrax L., Trachurus trachurus L. and Scomber colias Gmelin from North East Atlantic Ocean was $1.3 \pm 2.5$ items per individual [28]. Microplastics abundance in riverine fish in tributaries of Lake Michigan, USA ranged from $10.0 \pm 2.30$ to $13.0 \pm 1.60$ items $\mathrm{fish}^{-1}$ and was not significantly different among the three rivers, the Muskegon River, the Milwaukee River, and the St. Joseph River [20].

Table 1

Dimensional features of the dace, the Tom River, Tomsk, April 01, 2020

\begin{tabular}{|l|c|c|c|c|}
\hline \multicolumn{1}{|c|}{ Parameters } & $\mathrm{L}, \mathrm{cm}$ & $1, \mathrm{~cm}$ & $\mathrm{Q}, \mathrm{g}$ & $\mathrm{q}, \mathrm{g}$ \\
\hline $\mathrm{M} \pm \mathrm{m}_{\mathrm{M}}$ & $162 \pm 2.10$ & $133 \pm 1.68$ & $36.2 \pm 1.40$ & $31.7 \pm 1.46$ \\
\hline Min-Max & $148-175$ & $123-145$ & $27.7-43.9$ & $23.7-40.3$ \\
\hline Sample variance & 57.1 & 36.9 & 25.7 & 27.6 \\
\hline Standard deviation & 7.55 & 6.07 & 5.06 & 5.25 \\
\hline Coefficient of variation & 4.67 & 4.57 & 14.0 & 16.6 \\
\hline
\end{tabular}

Note: $L$ - Total length, $l$ - Standard length, $Q$ - Total weight, $q$ - Body weight without viscera.

Table 2

\section{The content of microplastic particles of different shapes and sizes in the fish gut (items fish ${ }^{-1}$ )}

\begin{tabular}{|l|c|c|c|c|c|c|c|c|c|}
\hline \multicolumn{1}{|c|}{ Parameters } & $\begin{array}{c}\text { Sphe- } \\
\text { res }\end{array}$ & Films & Fibers & $\begin{array}{c}\text { Frag- } \\
\text { ments }\end{array}$ & $<0.15$ & $\begin{array}{c}0.15- \\
0.30\end{array}$ & $\begin{array}{c}0.30- \\
1.00\end{array}$ & $\begin{array}{c}1.00- \\
2.00\end{array}$ & $\begin{array}{c}\text { Total } \\
\text { items } \\
\text { fish }^{-1}\end{array}$ \\
\hline $\mathrm{M} \pm \mathrm{m}_{\mathrm{M}}$ & $\begin{array}{c}31.5 \\
\pm 24.4\end{array}$ & $\begin{array}{c}14.9 \\
\pm 2.10\end{array}$ & $\begin{array}{c}13.9 \\
\pm 2.90\end{array}$ & $\begin{array}{c}144 \\
\pm 10.2\end{array}$ & $\begin{array}{c}162 \\
\pm 27.9\end{array}$ & $\begin{array}{c}24.2 \\
\pm 2.50\end{array}$ & $\begin{array}{c}16.2 \\
\pm 4.00\end{array}$ & $\begin{array}{c}1.20 \\
\pm 0.60\end{array}$ & $\begin{array}{c}204 \\
\pm 28.7\end{array}$ \\
\hline Min-Max & $\begin{array}{c}0.00- \\
523\end{array}$ & $\begin{array}{c}5.00- \\
26.0\end{array}$ & $\begin{array}{c}2.00- \\
35.0\end{array}$ & $96.0-225$ & $\begin{array}{c}74.0- \\
468\end{array}$ & $\begin{array}{c}11.0- \\
39.0\end{array}$ & $\begin{array}{c}1.00- \\
37.0\end{array}$ & $\begin{array}{c}0.00- \\
7.00\end{array}$ & $114-512$ \\
\hline Standard deviation & 88.0 & 7.60 & 10.4 & 36.8 & 101 & 9.00 & 14.5 & 2.00 & 104 \\
\hline $\begin{array}{l}\text { Coefficient of } \\
\text { variation }\end{array}$ & 279 & 50.9 & 74.8 & 25.7 & 62.0 & 37.1 & 89.1 & 173 & 50.7 \\
\hline
\end{tabular}

Thus, river fish are in some cases characterized by a relatively higher content of microplastics in the gastrointestinal tract as compared to sea fish. Riverine fish are more susceptible to ingesting microplastics because watercourses flow through many settlements which are anthropogenic sources of primary microplastics and secondary microplastics derived from plastic waste. Accumulation of microplastics in water systems in proximity to cities with a relatively high plastic use was documented in several studies reviewed by Wong et al. [22]. According to the review, microplastics were more common in areas with a high population density or proximity to urban centers. A study on microplastics in the Laurentian Great Lakes attributed the large spatial variability of pollution to population density by Eriksen et al. [29]. The urban sources of microplastics were also reported by Sanchez et al. [30] who detected the presence of microplastics in the 
guts of gudgeon (Gobio gobio L.) sampled from French urban rivers whereas none were found in gudgeons from sparsely populated areas.

In our study, $100 \%$ of the fish contained microplastics in their gut. As previously shown, $28 \%$ of 76 sea fish in Indonesia contained microparticles in the gut [31]; $67 \%$ of fish caught off the coast of Portugal contained at least one plastic particle [32]; in recent study microplastics were found in $42-62 \%$ of fish specimens from Portuguese coastal waters, depending on the species and their feeding type [26]. The frequency of occurrence of plastic debris per species from the Amazon River estuary varied between 18.7\% (Cynoscion microlepidotus Cuvier) and 100\% (Bagre marinus Mitchill, Caranx hippos L.), a positive correlation was found between fish standard length and number of microplastic particles in the gut [20]. $85 \%$ of fish individuals from Lake Michigan tributaries contained microplastic in their digestive tracts, plastic debris content in fish digestive tracts was different among species and feeding groups [21].

Microplastics found in dace from the Tom River were diverse in shape (Fig. 1) and included fragments, spheres, fibers and films ranging from $<0.15$ to $2.00 \mathrm{~mm}$.

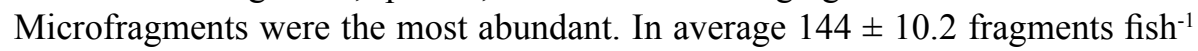
were detected, that comprised $70 \%$ of the total particles (Table 2 and Fig. 1). The remaining $30 \%$ of microplastic particles were spheres (16\%), films $(7 \%)$ and fibers (7\%) as shown in Fig. 2. The content of fragments of microplastics in the fish gut was significantly higher $(p \leq 0.01)$ than other types of particles (Fig. 2).
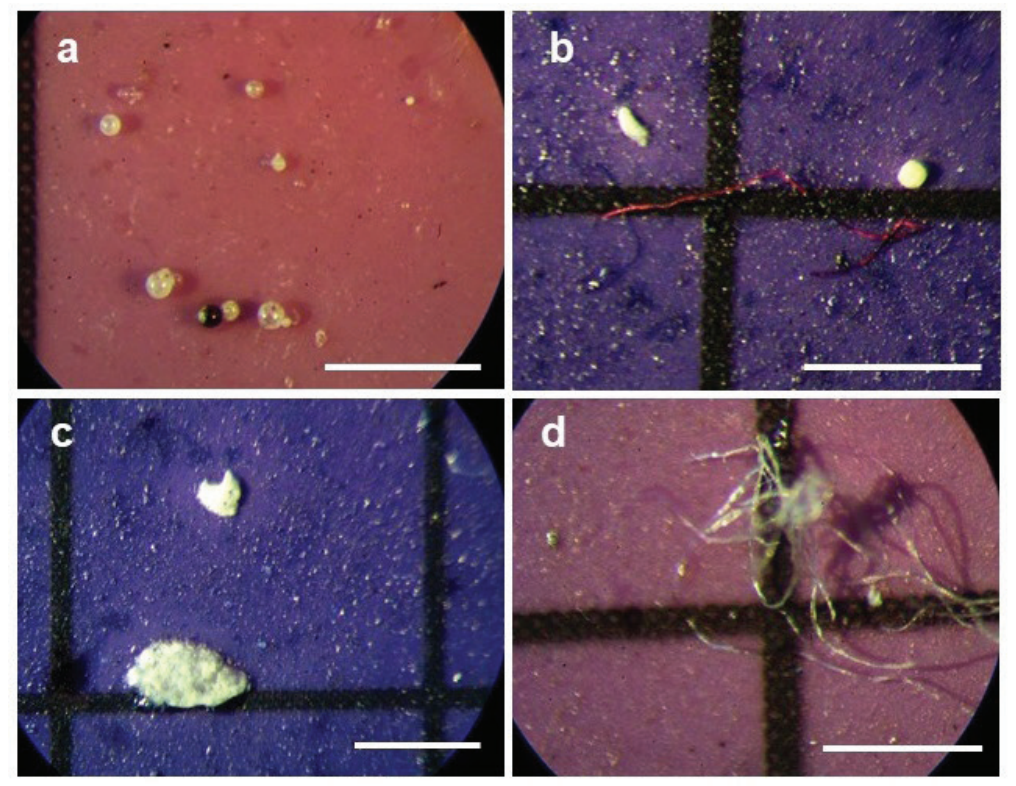

Fig. 1. Diversity of microplastics from the guts of the Tom River dace: spheres $(a)$, sphere, fibers and fragment (b), fragments (c), fibers $(d)$. Scale bar is $1 \mathrm{~mm}$. Microphotographs by Dmitry V. Antsiferov 


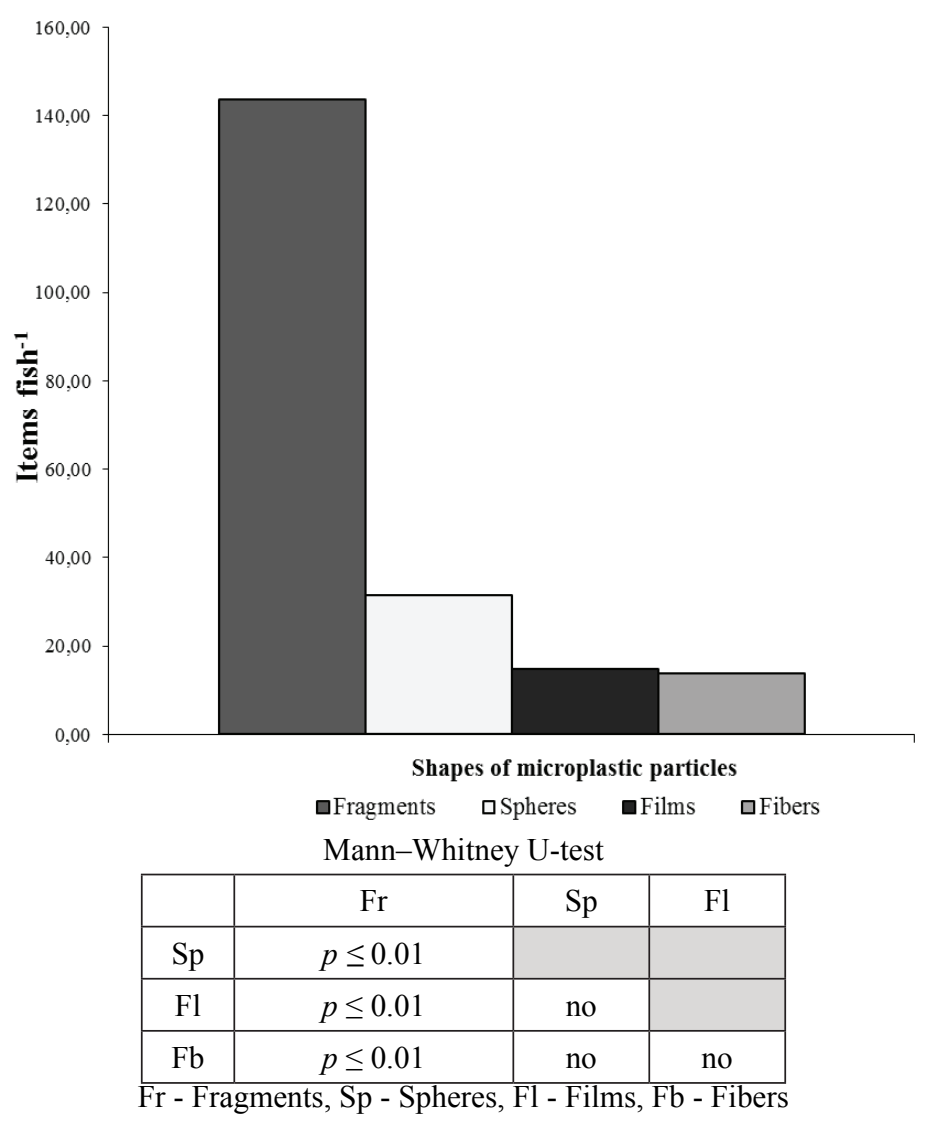

Fig. 2. Abundance of microplastic shapes in the guts of the Tom River dace $(a)$, differences in microplastic shapes abundance $(b)$

The prevalence of one type of particle or another may differ from site to site. In contrast to our data, fragments were rare in fish from Lake Michigan tributaries and accounted for approximately $2.5-3 \%$ while fibers comprised over $90 \%$ of the total microplastics [21]. Microspheres, namely pellets, were the most abundant (97.4\%) among plastic particles ingested by fish from the Amazon River estuary [20].

The majority of detected microplastic particles $\left(162 \pm 27.9\right.$ items fish $^{-1}$ or almost $80 \%$ ) were less than $0.15 \mathrm{~mm}$ by their largest dimension (Table 2 and Figure 3). The content of the smallest $(<0.15 \mathrm{~mm})$ microplastics in the fish gut was significantly higher $(p \leq 0.01)$ than other sizes of particles (Fig. 3). $20 \%$ of the particles detected in the fish gut were in the $0.15-2.00 \mathrm{~mm}$ size range. The largest fraction of the plastic particles between 0.15 and $2.00 \mathrm{~mm}$ were in the $0.15-0.30 \mathrm{~mm}$ size range followed by $0.30-1.00 \mathrm{~mm}$ sized particles (Table 2 and Fig. 3). Only one fragment of $3.00-4.00 \mathrm{~mm}$ size range was found in the studied dace digestive tracts. No particles of $2.00-3.00$ or $4.00-5.00 \mathrm{~mm}$ were detected. 


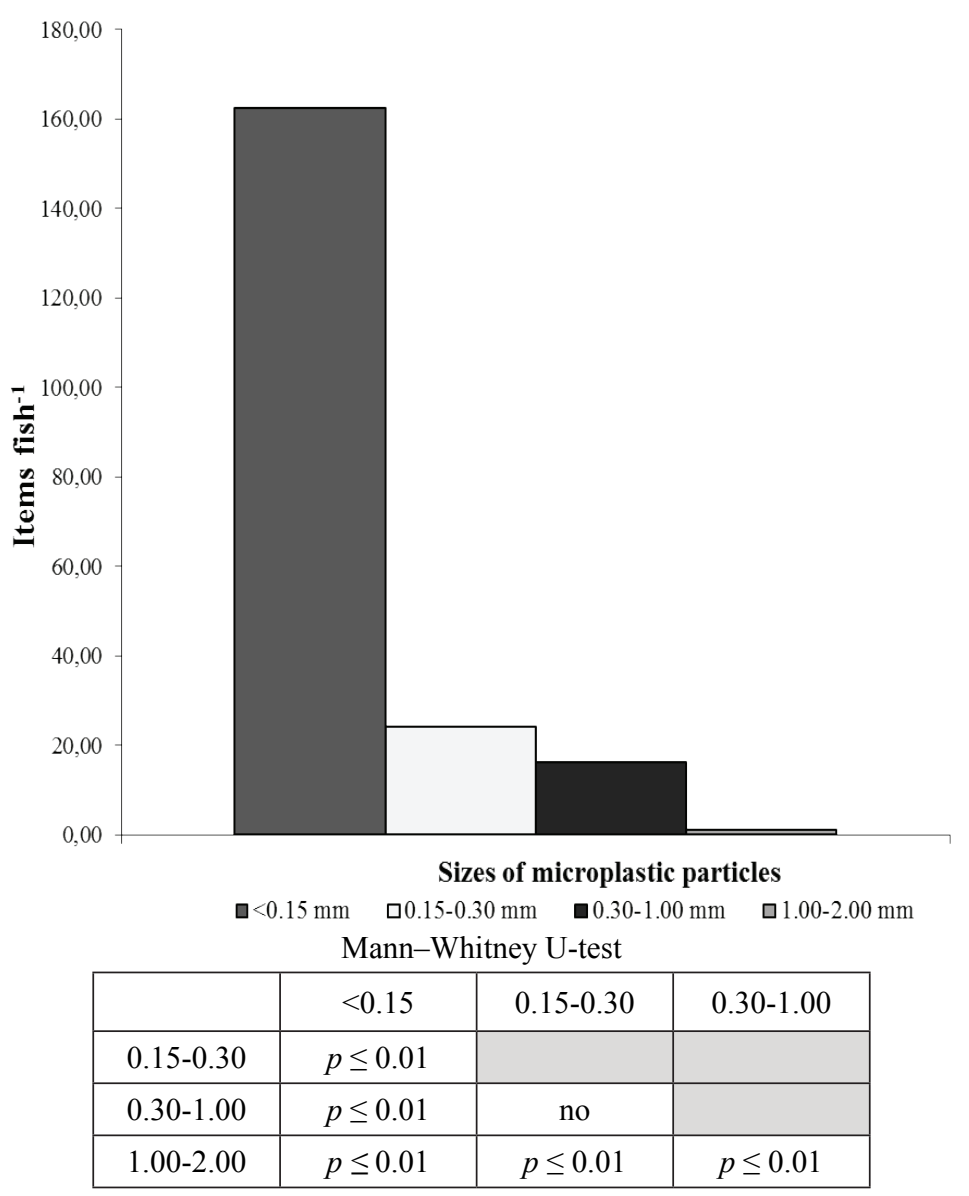

Fig. 3. Abundance of microplastic sizes in the guts of the Tom River dace $(a)$, differences in microplastic sizes abundance $(b)$

The size of microparticles of plastic ingested by aquatic organisms can affect their behavior in the body. It is accepted that microplastics of size less than $0.150 \mathrm{~mm}$ are absorbed by the intestine [10]. Micro- and nanoplastics can translocate from the intestine to the circulatory system or surrounding tissue and persist in the animal's body [11], promoting uptake of plastic debris in food chains.

\section{Conclusions}

Preliminary assessment conducted in this study suggests that the abundance of microplastics in fish of the Tom River is very high. $100 \%$ of thirteen dace (Leuciscus leuciscus L.) individuals from the Tom River caught in April, 2020 contained plastic debris in their gastrointestinal tract. In average $204 \pm 28.7$ items of microplastics were detected for one dace specimen. Fragments were the most 
abundant comprising $70 \%$ of the total particles, the remaining $30 \%$ of microplastic particles were spheres (16\%), films (7\%) and fibers (7\%). The vast majority of the detected particles (almost $80 \%$ ) were less than $0.15 \mathrm{~mm}$ by their largest dimension. $20 \%$ of the particles detected in the fish gut were in the $0.15-2.00 \mathrm{~mm}$ size range.

There were no significant differences in the abundance of microplastics in the gastrointestinal tract of fish between groups of males and females, as well as between groups of different ages. To identify such relationships, a long-term and large-scale study should be carried out.

\section{References}

1. Rochman CM and Hoellein T. The global odyssey of plastic pollution. Thinking big about small particles reveals new features of the microplastic cycle. Science. 2020;368:11841185. doi: 10.1126/science.abc4428

2. Thompson RC, Olsen Y, Mitchell PP, Davis A, Rowland SJ, John AW, McGonigle D, Russell AE. Lost at sea: Where is all the plastic? Science. 2004;304:838. doi: 10.1126/ science.1094559

3. Bergmann M, Gutow L, Klages M. Marine anthropogenic litter. Berlin, Germany: Springer Publ.; 2015. 447 p.

4. Hartmann NB, Hüffer T, Thompson RC, Hassellöv M, Verschoor A, Daugaard AE, Rist S, Karlsson T, Brennholt N, Cole M, Herrling MP, Hess MC, Ivleva NP, Lusher AL, Wagner M. Are we speaking the same language? Recommendations for a definition and categorization framework for plastic debris. Environmental Science and Technology. 2019;53(3):10391047. doi: 10.1021/acs.est.8b05297

5. Chubarenko I, Esiukova E, Khatmullina L, Lobchuk O, Grave A, Kileso A, Haseler M. From macro to micro, from patchy to uniform: Analyzing plastic contamination along and across a sandy tide-less coast. Marine Pollution Bulletin. 2020;156:111198. doi: 10.1016/j. marpolbul.2020.111198

6. Rochman CM, Browne MA, Halpern BS, Hentschel BT, Hoh E, Karapanagioti HK, RiosMendoza LM, Takada H, Teh S, Thompson RC. Policy: Classify plastic waste as hazardous. Nature. 2013;494:69-171. doi: 10.1038/494169a

7. Browne MA, Dissanayake A, Galloway TS, Lowe DM, Thompson RC. Ingested microscopic plastic translocates to the circulatory system of the mussel, Mytilus edulis (L.). Enviromental Science and Technology. 2008;42:5026-5031. doi: 10.1021/es800249a

8. Wang $\mathrm{W}, \mathrm{Ge} \mathrm{J}, \mathrm{Yu} \mathrm{X}$. Bioavailability and toxicity of microplastics to fish species: A review. Ecotoxicology and Environmental Safety. 2000;189:109913. doi: 10.1016/j. ecoenv.2019.109913

9. Farrell P, Farrell P, and Nelson K. Trophic level transfer of microplastic: Mytilus edulis (L.) to Carcinus maenas (L.). Environmental Pollution. 2013;177:1-3. doi: 10.1016/j. envpol.2013.01.046

10. Lusher AL, Hollman PCH, Mendoza-Hill JJ. Microplastics in fisheries and aquaculture: status of knowledge on their occurrence and implications for aquatic organisms and food safety. FAO Fisheries and Aquaculture Technical Paper, No. 615. Rome, Italy: FAO; 2017. 126 p.

11. Smith M, Love DC, Rochman CM, Neff RA. Microplastics in Seafood and the Implications for Human Health. Current Environmental Health Reports. 2018;5:375-386. doi: 10.1007/ s40572-018-0206-Z

12. Campanale C, Massarelli C, Savino I, Locaputo V, Uricchio VF. A detailed review study on potential effects of microplastics and additives of concern on human health. Int $J$ Environmental Research and Public Health. 2020;17:1212. doi: 10.3390/ijerph17041212 
13. Li J, Qu X, Su L, Zhang W, Yang D, Kolandhasamy P, Li D, Shi H. Microplastics in mussels along the coastal waters of China. Environmental Pollution. 2016;214:177-184. doi: 10.1016/j.envpol.2016.04.012

14. Vandermeersch G, Van Cauwenberghe L, Janssen CR, Marques A, Granby K, Fait G, Kotterman MJ, Diogene J, Bekaert K, Robbens J, Devriese L. A critical view on microplastic quantification in aquatic organisms. Environmental Research. 2015;143:4655. doi: 10.1016/j.envres.2015.07.016

15. Jahan S, Strezov V, Weldekidan H, Kumar R, Kan T, Sarkodie SA, He J, Dastjerdi B, Wilson SP. Interrelationship of microplastic pollution in sediments and oysters in a seaport environment of the eastern coast of Australia. Science of the Total Environment. 2019;695:133924. doi: 10.1016/j.scitotenv.2019.133924

16. Nadal MA, Alomar C, Deudero S. High levels of microplastic ingestion by the semipelagic fish bogue Boops boops (L.) around the Balearic Islands. Environmental Pollution. 2016;214:517-523. doi: 10.1016/j.envpol.2016.04.054

17. Bellas J, Martínez-Armental J, Martínez-Cámara A, Besada V, Martínez-Gómez C. Ingestion of microplastics by demersal fish from the Spanish Atlantic and Mediterranean coasts. Marine Pollution Bulletin. 2016;109:55-60. doi: 10.1016/j.marpolbul.2016.06.026

18. Giani D, Baini M, Galli M, Casini S. Microplastics occurrence in edible fish species (Mullus barbatus and Merluccius merluccius) collected in three different geographical sub-areas of the Mediterranean Sea. Marine Pollution Bulletin. 2019;140:129-137. doi: 10.1016/j. marpolbul.2019.01.005

19. Capone A, Petrillo M, Misic C. Ingestion and elimination of anthropogenic fibres and microplastic fragments by the European anchovy (Engraulis encrasicolus) of the NW Mediterranean Sea. Marine Biology. 2020;167:166. doi: 10.1007/s00227-020-03779-7

20. Pegado TSES, Schmid K, Winemiller KO, Chelazzi D, Cincinelli A, Dei L, Giarrizzo T. First evidence of microplastic ingestion by fishes from the Amazon River estuary. Marine Pollution Bulletin. 2018;133:814-821. doi: 10.1016/j.marpolbul.2018.06.035

21. McNeish RE, Kim LH, Barrett HA, Mason SA, Kelly JJ, Hoellein TJ. Microplastic in riverine fish is connected to species traits. Scientific Reports. 2018;8:11639. doi: 10.1038/ s41598-018-29980-9

22. Wong JKH, Lee KK, Tang KHD, Yap P-S. Microplastics in the freshwater and terrestrial environments: Prevalence, fates, impacts and sustainable solutions. Science of the Total Environment. 2020;719:137512, doi: 10.1016/j.scitotenv.2020.137512

23. Kottelat M. and Freyhof J. Handbook of European Freshwater Fish. Berlin, Germany: Kottelat, Cornol \& Freyhof Publ.; 2007. 646 p.

24. Pravdin IF. Rukovodstvo po izucheniyu ryb [Guide to fish study]. Moscow, Russia: Pishchevaya promyshlennost' Publ.; 1966. 376 p. In Russian

25. Claessens M, Van Cauwenberghe L, Vandegehuchte MB, Janssen CR. New techniques for the detection of microplastics in sediments and field collected organisms. Marine Pollution Bulletin. 2013;70:227-233. doi: 10.1016/j.marpolbul.2013.03.009

26. Cowger W, Gray AB, Eriksen M, Moore C, Thiel M. Evaluating wastewater effluent as a source of microplastics in environmental samples. In: Microplastics in Water and Wastewater. Karapanagioti HK and Kalavrouziotis IK, editors. London, UK: IWA Publishing; 2019. pp. 109-131. doi: 10.2166/9781789060034_0109

27. Mann HB, Whitney DR. On a test of whether one of two random variables is stochastically larger than the other. Annals of Mathematical Statistics.1947;18:50-60.

28. Barboza LGA, Lopes C, Oliveira P, Bessa F, Otero V, Henriques B, Raimundo J, Caetano M, Vale C, Guilhermino L. Microplastics in wild fish from North East Atlantic Ocean and its potential for causing neurotoxic effects, lipid oxidative damage, and human health risks associated with ingestion exposure. Science of the Total Environment. 2020;717:134625. doi: 10.1016/j.scitotenv.2019.134625. 
29. Eriksen M, Mason S, Wilson S, Box C, Zellers A, Edwards W, Farley H, Amato S. Microplastic pollution in the surface waters of the Laurentian Great Lakes. Marine Pollution Bulletin. 2013;77:177-182. doi: 10.1016/j.marpolbul.2013.10.007

30. Sanchez W, Bender C, Porcher JM. Wild gudgeons (Gobio gobio) from French rivers are contaminated by microplastics: preliminary study and first evidence. Environmental Research. 2014;128:98-100. doi: 10.1016/j.envres.2013.11.004

31. Rochman C, Tahir A, Williams S, Baxa DV, Lam R, Miller JT, Teh F-C, Werorilangi S, and Teh SJ. Anthropogenic debris in seafood: Plastic debris and fibers from textiles in fish and bivalves sold for human consumption. Scientific Reports. 2015;5:14340. doi: 10.1038/ srep 14340

32. Neves D, Sobral P, Ferreira JL, Pereira T. Ingestion of microplastics by commercial fish off the Portuguese coast. Marine Pollution Bulletin. 2015;101:119-126. doi: 10.1016/j. marpolbul.2015.11.008

Received 18 October 2020; Revised 01 December 2020; Accepted 03 December 2020; Published 29 December 2020

\author{
Author info: \\ Frank Yulia A, Cand. Sci. (Biol.), Head of the Laboratory of Industrial Microbiology, Institute of Biology, \\ Tomsk State University, 36 Lenin Ave., Tomsk 634050, Russian Federation; Scientific Vice-Director, \\ Darwin LLC, 28/3 Vysotskogo Str., Tomsk 634040, Russian Federation. \\ ORCID iD: https://orcid.org/0000-0001-6347-4009 \\ E-mail: yulia.a.frank@gmail.com \\ Vorobiev Egor D, Student, Institute of Biology, Tomsk State University, 36 Lenin Ave., Tomsk 634050, \\ Russian Federation. \\ E-mail: vorobievegor@gmail.com \\ ORCID iD: https://orcid.org/0000-0001-5764-6134
}

Babkina Irina B, Cand. Sci. (Biol.), Assoc. Prof., Department of Ichthyology and Hydrobiology, Institute of Biology, Tomsk State University, 36 Lenin Ave., Tomsk 634050, Russian Federation.

E-mail: bibsphera@gmail.com

Antsiferov Dmitry V, Cand. Sci. (Biol.), Head of the Department of Biopreparations Production, Darwin LLC, 28/3 Vysotskogo Str., Tomsk 634040, Russian Federation.

E-mail: dmitry.antsiferov@gmail.com

ORCID iD: https://orcid.org/0000-0002-1865-1675

Vorobiev Danil S, Dr. Sci. (Biol.), Director of the Institute of Biology, Tomsk State University, 36 Lenin Ave., Tomsk 634050, Russian Federation.

E-mail: danilvorobiev@yandex.ru

ORCID iD: https://orcid.org/0000-0003-4397-4406

For citation: Frank YuA, Vorobiev ED, Babkina IB, Antsiferov DV, Vorobiev DS. Microplastics in fish gut, first records from the Tom River in West Siberia, Russia. Vestnik Tomskogo gosudarstvennogo universiteta. Biologiya $=$ Tomsk State University Journal of Biology. 2020;52:130-139. doi: 10.17223/19988591/52/7

Для цитирования: Frank Yu.A, Vorobiev E.D., Babkina I.B., Antsiferov D.V., Vorobiev D.S. Microplastics in fish gut, first records from the Tom River in West Siberia, Russia // Вестн. Том. гос. ун-та. Биология. 2020. № 52. С. 130-139. doi: 10.17223/19988591/52/7 